\title{
Jamaican Field Cricket, Gryllus assimilis (Fabricius) (Insecta: Orthoptera: Gryllidae) ${ }^{1}$
}

T. J. Walker ${ }^{2}$

\section{Introduction}

This species was first described from Jamaica and is widespread in the West Indies. It may have first become established in south Florida as recently as the early 1950's. Its scientific name (Gryllus assimilis or Acheta assimilis) was applied to all New World field crickets until 1957.

For information on other Florida field and house crickets see:

http://creatures.ifas.ufl.edu/misc/crickets/ crickets.html.

\section{Distribution}

In the United States, Jamaican field crickets are known only from south peninsular Florida and southernmost Texas.

\section{Identification}

Jamaican field crickets are not as dark as other Florida field crickets. The arms of the Y-shaped "ecdysial suture" are well defined, and most of the areas around the eyes are light yellow-brown. The pronotum has a dense brown pubescence that makes

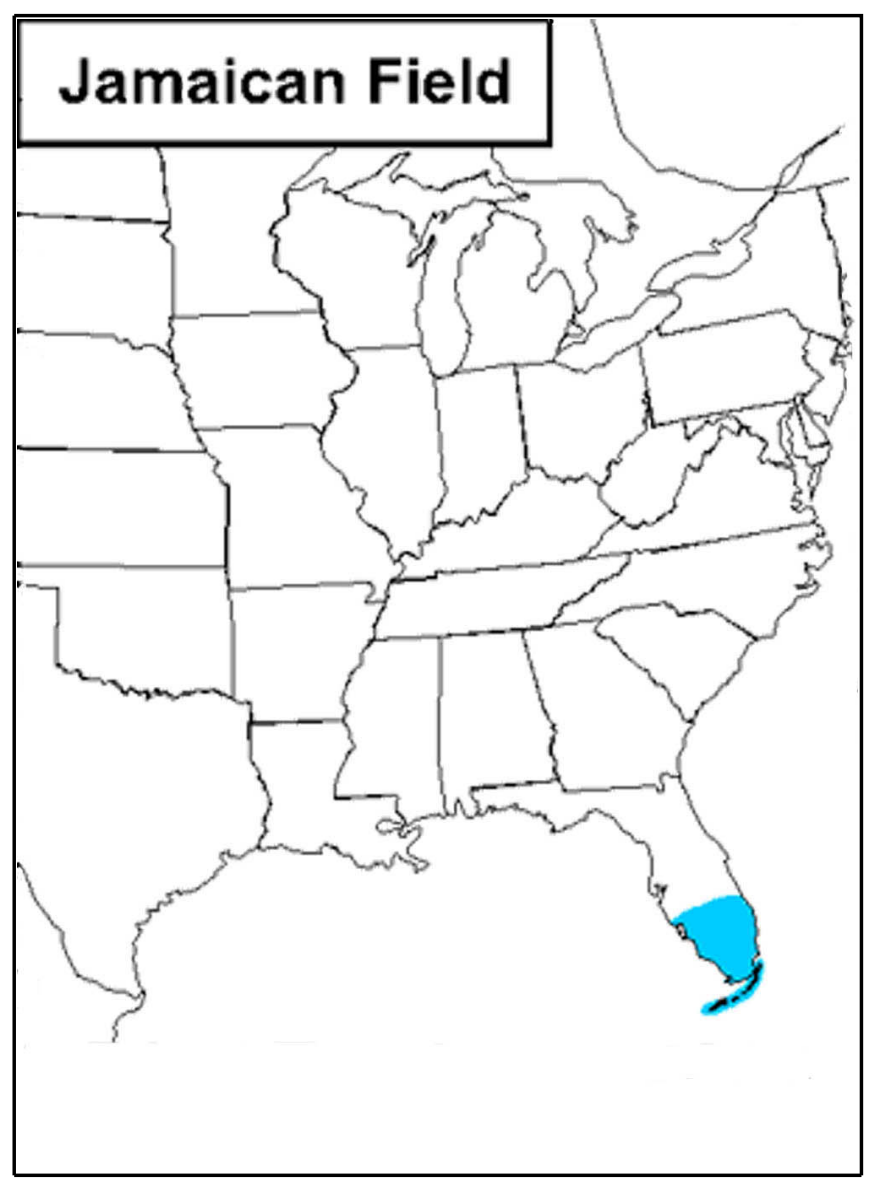

Figure 1. Distribution of Jamaican field cricket in the United States.

1. This document is EENY-069, one of a series of Featured Creatures from the Entomology and Nematology Department, Florida Cooperative Extension Service, Institute of Food and Agricultural Sciences, University of Florida. Published: January 1999. Reviewed: May 2003. This document is also available on Featured Creatures Website at http://creatures.ifas.ufl.edu. Please visit the EDIS Website at http://edis.ifas.ufl.edu.

2. T. J. Walker, professor, Entomology and Nematology Department, Institute of Food and Agricultural Sciences, University of Florida, Gainesville, 32611.

The Institute of Food and Agricultural Sciences (IFAS) is an Equal Employment Opportunity - Affirmative Action Employer authorized to provide research, educational information and other services only to individuals and institutions that function without regard to race, creed, color, religion, age, disability, sex, sexual orientation, marital status, national origin, political opinions or affiliations. For information on obtaining other extension publications, contact your county Cooperative Extension Service office. Florida Cooperative Extension Service / Institute of Food and Agricultural Sciences / University of Florida / Larry R. Arrington, Interim Dean 
this field cricket appear "fuzzier" than the other

Florida species. All adults have long hind wings.

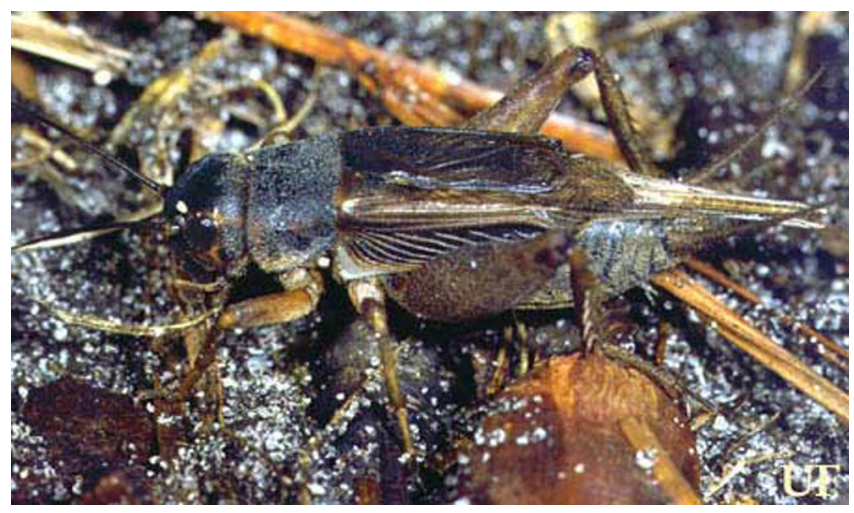

Figure 2. Jamaican field cricket, Gryllus assimilis (Fabricius), male. Credits: Paul M. Choate, University of Florida

\section{Life Cycle}

Jamaican field crickets probably occur in all stages at all times of year. Supporting this conjecture is the species' tropical origin and its rapid, synchronous development in laboratory colonies. Its relatively large size and ease of rearing might make it competitive with the house cricket as a species to be reared and sold for pet food.

\section{Habitat}

This species is characteristic of lawns, weedy fields, roadsides and other open areas. It sometimes flies to lights in significant numbers. An African field cricket in which all adults are long-winged was found flying at sea more than 500 miles from shore. Thus it is possible that the Jamaican field cricket reached Florida from the West Indies under its own power.

\section{Song}

The calling song ( $689 \mathrm{~Kb}$ wav file) of this species is a brief chirp repeated about once per second. Unlike Floridas other chirping field crickets, each chirp usually has seven or more pulses, with the initial ones being briefer and more rapidly delivered than the terminal ones (graphs). The pulse rate is so high and the pulse intervals so brief that the chirp sounds more like a continuous sound than in other chirping species.

\section{Selected References}

Alexander, R. D., and T. J. Walker. 1962. Two introduced field crickets new to eastern United States (Orthoptera: Gryllidae). Annals of the Entomological Society of America 55: 90-94. 